\title{
Indeks Literasi Digital Generasi Milenial di Kabupaten Bandung
}

\author{
Kharisma Nasionalita ${ }^{1}$, Catur Nugroho ${ }^{2}$ \\ ${ }^{1,2}$ Program Studi Ilmu Komunikasi, Fakultas Komunikasi dan Bisnis, Telkom University \\ Jl. Telekomunikasi No.1 Terusan Buah Batu, Bandung 40257 \\ Email: nasionalita.kharisma@gmail.com¹; denmasnuno@telkomuniversity.ac.id²* \\ *Corresponding author
}

\begin{abstract}
Various issues such as hoax information, privacy violations, cyberbullying, violent and pornographic content, and digital media addiction are considered to be the latest digital society issues. In addition to gaps, various cases of Internet abuse are also rampant, ranging from Internet fraud, addiction, violation of privacy, bias to reality, to the latest is the spread of hoaxes or false information. This study aims to determine the level of digital literacy for the millennial generation in Bandung Regency. The research method used is quantitative with a survey approach. The population and sample taken were the new millennial generation, namely the group of adolescents or young people aged high school (SMA) in Bandung district. This study seeks to map to what extent the digital literacy level of adolescents in Bandung district. The results showed that the digital literacy level of the millennial generation in Bandung district is at an intermediate level. The contribution of this research is in the form of new policy recommendations for the Bandung Regency government to carry out initial mapping of the level of digital literacy.
\end{abstract}

Keywords: Bandung; Digital Literacy; Index; Millennial Generation

\begin{abstract}
Abstrak
Beragam persoalan seperti informasi hoaks, pelanggaran privasi, cyberbullying, konten kekerasan dan pornografi, dan adiksi media digital dianggap sebagai persoalan masyarakat digital terkini. Selain kesenjangan terjadi, berbagai kasus penyalahgunaan Internet juga marak, mulai dari Internet fraud, adiksi, pelanggaran privasi, bias realitas hingga paling mutakhir adalah meluasnya hoaks atau informasi palsu. Penelitian ini bertujuan untuk mengetahui tingkat literasi digital generasi milenial di Kabupaten Bandung. Penelitian ini menggunakan metode penelitian kuantitatif dengan pendekatan survei. Populasi dan sampel yang diambil adalah generasi milenial baru yaitu kelompok remaja atau kaum muda usia Sekolah Menengah Atas (SMA) di kabupaten Bandung. Penelitian ini berusaha untuk memetakan sampai dimana tingkat literasi digital remaja di kabupaten Bandung. Hasil penelitian menunjukkan bahwa tingkat literasi digital generasi milenial di kabupaten Bandung berada pada level intermediate. Kontribusi penelitian ini berupa rekomendasi kebijakan baru kepada pemerintah Kabupaten Bandung agar melakukan pemetaan awal terkait tingkat literasi digital.
\end{abstract}

Kata Kunci: Bandung; Literasi Digital; Indeks; Generasi Milenial

\section{Pendahuluan}

Perkembangan teknologi telah mendorong transformasi dari masa ke masa. Kita bisa melihat dari era paling awal pada teknologi media komunikasi yang sederhana hingga yang kompleks seperti saat ini, perkembangan itu akan memberikan perbedaan cara berkomunikasi. Teknologi komunikasi di Indonesia semakin pesat di Indonesia didukung oleh perkembangan Internet. Internet merupakan salah satu bentuk dari dari perkembangan teknologi informasi dan komunikasi Internet adalah jaringan global yang menghubungkan seluruh komputer di dunia meskipun berbeda sistem operasi dan mesin. Kehadiran Internet membuka jalan new media untuk hadir ditengah masyarakat yang memberikan layanan kemudahan dalam berinteraksi serta berkomunikasi dengan sesama penggunamembawapengaruhbesardankemudian membentuk budaya baru dalam berkomunikasi.

Data terakhir dari Indonesia Digital Landscape 2018, penetrasi Internet di Indonesia mencapai angka $79 \%$ dengan jumlah total pengguna Internet 143 juta. Smartphone memiliki andil dalam tingginya penetrasi Internet di Indonesia. Hampir 90\% pengguna Internet 
mengakses melalui smartphone. Penetrasi Internet semakin tinggi didukung oleh adanya platform media yang konvergen. Menurut Onno W Purbo, Internet merupakan sebuah media yang digunakan untuk mengefisiensikan sebuah proses komunikasi yang disambungan dengan berbagai aplikasi, seperti web, VoIP, Email (Purbo, 2018). Internet membuat dunia seakan melebihi kapasitas di luar ambang batas dan semua orang pun kini dapat berperan dalam menyiarkan apa saja. Internet dapat memberikan berbagai macam informasi yang dibutuhkan dan yang tidak dibutuhkan oleh masyarakat. Inilah yang kemudian menjadi masalah yang muncul dalam perkembangan teknologi informasi.

Masalah krusial pertama, Informasi yang tersebar di Internet pun bermacam macam, mulai dari informasi yang fakta sampai informasi yang fiktif. Informasi pun mengalir deras, cepat dan tidak dapat dibendung. Individu yang tidak memiliki kecakapan dalam memilih dan memilah serta mengevaluasi secara kritis atas aliran informasi, maka manusia akan terjebak pada kondisi yang disebut Alvin Toffler sebagai "Information overload" suatu kondisi dimana seseorang menjadi sulit memahami permasalahan isu dan kemudian mengambil keputusan dikarenakan informasi yang berlebih. Akibat ketidakcakapan merespon dan mengelola informasi, kondisi akan lebih buruk daripada information overload, manusia dalam kebingungannya terjebak dalam cyberswamp atau rawa informasi yang pekat. Jebakan cyberswamp membuat manusia lumpuh melawan arus informasi yang deras, tidak mampu merespon dan membiarkan segala informasi menggerusnya.

Masyarakat informasi (information society) seperti yang diungkap oleh Rogers (2001) digambarkan sebagai masyarakat yang sebagian besar angkatan kerjanya merupakan pekerja di bidang informasi dan informasi merupakan elemen penting dalam kehidupan (Rogers, 2001). Informasi disebut sebagai sebuah komoditas karena sangat penting bagi kehidupan. Rogers lebih lanjut menekankan informasi sebagai salah satu diantara tiga sumber daya dasar (Basic resouces) selain potensi material dan energi (Rogers, 2001). Informasi kemudian dianggap tidak memiliki kegunaan praktikal bila tidak dimaknai dan dioperasionalkan, dan informasi hanya dapat dioperasionalkan melalui komunikasi. Inilah masalah krusial yang kedua yang meliputi perkembangan teknologi informasi dan komunikasi. Fleksibilitas kreasi konten informasi merupakan daya tawar dari teknologi informasi dan komunikasi. Fleksibilitas tersebut memberi celah pada penciptaan informasi sebagai komoditas yang disengaja, disinformasi akan muncul. Disinformasi merupakan sebuah informasi yang salah yang sengaja dikreasikan.

Teknologi dianggap sebagai perluasan dari eksistensi atau kemampuan manusia (the extensions of man). Ketika mesin merupakan perluasan dari tangan manusia untuk bergerak, teknologi juga melibatkan kinerja otak. Teknologi didesain dari tindakan yang terencana yang mereduksi ketidakpastian dalam relasi sebab akibat, yang melibatkan pencapaian hasil yang diharapkan. Setiap teknologi biasanya berkaitan dengan aspek hardware (terdiri dari objek fisik atau materi) dan software (terdiri atas basis informasi bagi hardware).

Teknologi sendiri tidak hanya dimaknai sebagai alat, namun juga melibatkan kemampuan manusia dalam memaknainya. Kecakapan dibutuhkan untuk memaknai segala platform teknologi informasi dan komunikasi, termasuk teknologi dalam sumber digital. Fenomena seperti cyberswamp dan disinformasi merupakan bagian dari ketidakcakapan dalam memaknai teknologi itu sendiri.

Sebagai salah satu majalah berita terbesar di dunia, pada 20 Mei 2013 majalah TIME menjadikan generasi millennial sebagai sampul depan. Menurut majalah TIME, generasi millennial merupakan generasi yang terlalu aktif di Internet, memiliki tingkat narsisme, materialisme, dan kecanduan teknologi yang 
lebih tinggi dibandingkan dengan generasi lain. Generasi millennial bisa mengunggah puluhan foto diri, foto makanan, dan foto lokasi liburan di media sosial mereka setiap minggunya (Alfyonita et al., 2019).

Lyons (2004) menyatakan bahwa salah satu ciri-ciri dari generasi millennial adalah pemakai media sosial yang fanatik dan kehidupannya sangat terpengaruh dengan perkembangan teknologi (Lyons, 2004). Tidak heran lagi apabila sekarang media sosial Instagram dipenuhi oleh para generasi millennial yang sering berbagi foto maupun kegiatan sehari-hari.

Urgensi mengenai literasi digital juga sejalan dengan concern negara (pemerintah). Kementerian Komunikasi dan Informatika (Kemkominfo) memiliki roadmap menuju Indonesia Digital pada tahun 2020. Sejumlah tahap yang harus dilalui telah disiapkan untuk mencapai tujuan. Berdasarkan roadmap pada tahap pertama atau 2010-2012, yaitu masuk Indonesia Connected, dimana dalam tahap ini seluruh desa ada akses telepon, seluruh kecamatan harus ada akses internet. Pada tahap kedua tahun 2012-2014 Kemkominfo memiliki misi Indonesia informatif, yaitu masyarakat Indonesia sudah masuk dalam masyarakat Informasi. Hal-hal inilah yang harus diantisipasi dan betapa pentingnya penyebaran informasi. Saat ini televisi telah menjangkau daerah terluar Indonesia dan diharapkan dapat memenuhi kebutuhan informasi masyarakat di sana. Tetapi merupakan tugas selanjutnya adalah membekali masyarakat dengan edukasi yang cukup sehingga dapat menggunakan teknologi ini untuk kesejahteraannya bukan sebaliknya (Juditha, 2013).

Literasi media dimaknai sebagai sebuah kecakapan ketika berhadapan dengan media. Pemahaman literasi media atau melek media secara sederhana adalah bagaimana khalayak media mampu memilih atau menyaring isi pesan yang disampaikan oleh media (Novianti, Fatonah, Siti, 2016). Khalayak dalam mengkonsumsi pesan media mampu membedakan mana yang dianggap penting atau baik dan mana yang dianggap buruk. Jika bicara pada konteks media digital, literasi media digital dapat diartikan sebagai kecakapan individu ketika berhadapan dengan media digital. Pandangan umum masyarakat literasi media dekat dengan istilah "melek media", padahal artinya lebih luas dari itu.

Konsep literasi bersumber awal dari berkaitan dengan melek huruf, dipahami sebagai kemampuan individu membaca aksara dan medianya. Literasi digital sebagai suatu kemampuan untuk memahami dan menggunakan informasi dari berbagai infomasi dari berbagai sumber digital (Lankshear \& Knobel, 2006). Data dipahami bahwa kemampuan literasi tidak hanya berkaitan dengan membaca aksara saja, namun dibutuhkan pula proses berpikir dan mengevaluasi informasi yang ditemukan dalam sumber digital. Literasi digital adalah tentang penguasaan ide, serta pengetahuan tentang apa yang kita lihat di layar komputer saat menggunakan media jaringan (Lankshear \& Knobel, 2006).

Gilster bukanlah orang pertama yang menggunakan frase "literasi digital". Lanham (1995) pertama kali memunculkan istilah "literasi multimedia", istilah yang cukup berbeda dengan literasi tradisional. Argumen Lanham karena sumber digital dapat menghasilkan berbagai bentuk informasi, seperti teks, gambar, suara, dan lain-lain. Diperlukan bentuk literasi media yang baru untuk memahami bentukbentuk presentasi yang baru tersebut. David Bawden, yang menggunakan istilah literasi digital sejak tahun 1990-an, sebagai kemampuan membaca dan memahami item informasi dalam format hypertext atau multimedia yang kemudian tersedia (Bawden, 2017).

Beragam persoalan seperti informasi hoax, pelanggaran privacy, cyberbullying, konten kekerasan dan pornografi, dan adiksi media digital dianggap sebagai persoalan masyarakat digital terkini. Indikasi masalah tersebut muncul karena rendahnya literasi digital di Indonesia. 
Kenyataan menunjukkan banyaknya jumlah pengguna Internet di Indonesia, serta tingginya frekuensi mengakses konten informasi dan media sosial, tidak serta merta menjamin "kedewasaan" netizen Indonesia dalam menggunakan Internet. Selain kesenjangan terjadi, berbagai kasus penyalahgunaan Internet juga marak, mulai dari Internet fraud, adiksi, pelanggaran privasi, bias realitas hingga paling mutakhir adalah meluasnya Hoax. Hal itu terjadi karena kurangnya literasi digital masyarakat Indonesia. Literasi digital ini tidak lepas dari kemampuan seseorang dalam menggunakan dan memanfaatkan media.

Penelitian terkait literasi digital dalam jurnal akademik pada awalnya banyak dilakukan oleh beberapa peneliti di Eropa dan Amerika. Salah satu penelitian mengenai literasi digital adalah dari Colin Lankshear dan Michele Knobel dari Montclair State University, Amerika Serikat dengan judul Digital Literacy and Digital Literacies; Policy, Pedagogy, and Research Consideration For Education (Lankshear \& Knobel, 2006). Lankshear dan Knobel mengidentifikasi literasi digital sebagai tujuan pendidikan formal. Meskipun definisi literasi digital memiliki pengertian yang bermacammacam, cakupan dan makna literasi digital tak jarang dianggap sebagai satu masalah. Lankshear dan Knobel berpendapat bahwa akun arus utama khas literasi digital sangat bermasalah, dimana pemahaman tentang literasi digital harus dipahami dalam kerangka yang beragam. Makalah ini menyimpulkan bahwa literasi digital tidak dapat disamakan dengan literasi fungsional dari media lama. Selain itu Lankshear dan Knobel mengidentifikasi beberapa implikasi dari argumen mengenai literasi digital untuk kebijakan pendidikan, pedagogi dan penelitian (Lankshear \& Knobel, 2006). Penelitian Lankshear dan Knobel tidak menjelaskan secara rinci mengenai perbedaan yang signifikan dari literasi media dengan literasi digital.
Penelitian mengenai literasi digital selanjutnya adalah dari Qory Qurratun A'yun, yang mengangkat tema tentang Tingkat Kompetensi Literasi Digital pada Remaja SMP, SMA dan Mahasiswa di Kota Surabaya (A'yuni, 2015). A'yun melakukan survei terhadap para remaja pelajar SMP dan SMA untuk mendapatkan gambaran tingkat kompetensi literasi digital remaja di kota Surabaya. Penelitian A'yun menggunakan komponenkomponen pencarian di internet, pandu arah hypertext, evaluasi konten informasi, serta penyusunan pengetahuan dari Gilster. Hasil penelitian tersebut menunjukkan bahwa tingkat literasi digital remaja di Surabaya berdasarkan aspek internet searching sudah tergolong tinggi, sedangkan berdasarkan aspek hypertextual navigation juga sudah tergolong tinggi. Tingkat literasi digital remaja berdasarkan aspek content evaluation masih tergolong sedang, dan berdasarkan aspek knowledge assembly sudah tergolong tinggi. Penelitian yang dilakukan pada tahun 2015 menggunakan aspek-aspek literasi digital dari Paul Gilster yang kurang sesuai dengan perkembangan teknologi dan media digital terkini, karena hanya menyangkut empat aspek yang lebih banyak terkait dengan penggunaan internet.

Permasalahan yang terjadi terkait penggunaan sumber digital oleh generasi millenial, maka penelitian ini dilakukan berdasarkan rumusan masalah mengenai bagaimana gambaran indeks literasi digital para generasi milenial di Kabupaten Bandung. Penelitian ini diharapkan dapat memberikan konstribusi dalam bidang teknologi informasi dan komunikasi, terutama dalam permasalahan literasi digital di wilayah Kabupaten Bandung. Selain itu penelitian ini diharapkan dapat menjadi bahan rujukan bagi daerah lain di Indoneisa yang memetakan tingkat literasi digital generasi muda. 


\section{Generasi Milenial}

Putra (2016) mengurai pemikiran para ahli mengenai definisi Generasi; Pertama, menurut Marnheim bahwa generasi merupakan suatu konstruksi sosial dimana didalamnya terdapat sekelompok orang yang memiliki kesamaan umur dan pengalaman historis yang sama. Kedua, menurut Ryder generasi adalah agregat dari sekelompok individu yang mengalami peristiwa-peristiwa yang sama dalam kurun waktu yang sama pula. Ketiga, Kupperschmidt dalam (Yanuar Surya Putra, 2016) mengatakan bahwa generasi adalah sekelompok individu yang mengidentifikasikan kelompoknya berdasarkan kesamaan tahun kelahiran, umur, lokasi, dan kejadiankejadian dalam kehidupan individu tersebut yang memiliki pengaruh signifikan dalam fase pertumbuhan mereka .
Dari beberapa penjelasan diatas, bisa disimpulkan bahwa generasi merupakan sekelompok individu yang memiliki rentang tahun kelahiran dan pengalaman yang sama. Howe \& Strauss membagi generasi berdasarkan tahun kelahiran dan kejadian historis yang sama (Home \& Strauss, 2018). Pembagian generasi juga dikemukakan oleh banyak ahli lainnya, ada beberapa perbedaan skema yang digunakan dalam penentuan generasi karena berasal dari berbagai negara yang berbeda. Salah satunya adalah pengelompokan generasi dari Putra berikut ini (Yanuar Surya Putra, 2016).

Dari data Tabel 1 pengelompokan generasi di atas (Jurnal Theoritical Review: Teori Perbedaan Generasi), perbedaan pengelompokan generasi memang tidak terlalu jauh. Menurut Howe \& Strauss (2000), generasi millennial merupakan

Tabel 1. Pengelompokan Generasi

\begin{tabular}{|c|c|c|c|c|c|}
\hline Sumber & & & Label & & \\
\hline $\begin{array}{l}\text { Tapscott } \\
(1998)\end{array}$ & - & $\begin{array}{c}\text { Baby Boom } \\
\text { Generation } \\
(1946-1964)\end{array}$ & $\begin{array}{c}\text { Generation } \\
\text { X } \\
(1965-1975)\end{array}$ & $\begin{array}{c}\text { Digital } \\
\text { Generation } \\
(1976-2000)\end{array}$ & - \\
\hline $\begin{array}{c}\text { Howe \& } \\
\text { Strauss } \\
(2000)\end{array}$ & $\begin{array}{c}\text { Silent } \\
\text { Generation } \\
(1925-1943)\end{array}$ & $\begin{array}{c}\text { Boom } \\
\text { Generation } \\
(1943-1960)\end{array}$ & $\begin{array}{c}\text { 13th } \\
\text { Generation } \\
(1961-1981)\end{array}$ & $\begin{array}{c}\text { Millenial } \\
\text { Generation } \\
(1982-2000)\end{array}$ & - \\
\hline $\begin{array}{l}\text { Zemke et } \\
\text { al }(2000)\end{array}$ & $\begin{array}{c}\text { Veterans } \\
(1922-1943)\end{array}$ & $\begin{array}{c}\text { Baby } \\
\text { Boomers } \\
(1943-1960)\end{array}$ & $\begin{array}{c}\text { Gen-Xers } \\
(1960-1980)\end{array}$ & $\begin{array}{c}\text { Nexters } \\
(1980-1999)\end{array}$ & - \\
\hline $\begin{array}{l}\text { Lancaster } \\
\& \& \\
\text { Stillman } \\
(2002)\end{array}$ & $\begin{array}{l}\text { Traditionalis } \\
(1900-1945)\end{array}$ & $\begin{array}{c}\text { Baby } \\
\text { Boomers } \\
(1946-1964)\end{array}$ & $\begin{array}{c}\text { Generation } \\
\text { Xers } \\
(1965-1980)\end{array}$ & $\begin{array}{c}\text { Generation Y } \\
(1981-1999)\end{array}$ & - \\
\hline $\begin{array}{l}\text { Martin \& } \\
\text { Tulgan } \\
(2002)\end{array}$ & $\begin{array}{c}\text { Silent } \\
\text { Generation } \\
(1925-1942)\end{array}$ & $\begin{array}{c}\text { Baby } \\
\text { Boomers } \\
(1946-1964)\end{array}$ & $\begin{array}{c}\text { Generation } \\
\text { X } \\
(1965-1977)\end{array}$ & $\begin{array}{c}\text { Millenials } \\
(1978-2000)\end{array}$ & - \\
\hline $\begin{array}{l}\text { Oblinger } \\
\text { \& } \\
\text { Oblinger } \\
(2005)\end{array}$ & $\begin{array}{l}\text { Matures } \\
(<1946)\end{array}$ & $\begin{array}{c}\text { Baby } \\
\text { Boomers } \\
\text { (1947-1964) }\end{array}$ & $\begin{array}{c}\text { Generation } \\
\text { Xers } \\
(1965-1980)\end{array}$ & $\begin{array}{c}\text { Gen- } \\
\text { Y/NetGen } \\
(1981-1995)\end{array}$ & $\begin{array}{c}\text { Post } \\
\text { Millenials } \\
\text { (1995- } \\
\text { present) }\end{array}$ \\
\hline
\end{tabular}

Sumber: Yanuar Surya Putra (2016) 
generasi yang lahir antara tahun 1982 hingga 2000. Martin \& Tulgan mengelompokkan generasi millennial merupakan kelahiran tahun 1978 hingga 2000 (Martin \& Tulgan, 2012). Lancaster \& Stillman menyatakan generasi millennial lahir pada rentang tahun 1981 hingga 1999 (Lancaster \& Stillman, 2011). Dari beragam perbedaan pengelompokan generasi, peneliti mengambil garis batas usia generasi millennial dari tahun 1980 hingga 2000.

Dapat dikatakan bahwa generasi millennial merupakan suatu kelompok individu yang lahir pada rentang tahun 1980 hingga 2000. Generasi millennial sering juga disebut sebagai generasi Y maupun Global Generations dengan rentang usia 19-38 tahun hingga tahun 2018 ini. Berbeda dengan generasi-generasi sebelumnya, generasi millennial dilahirkan dan dibesarkan seiring dengan berbagai kejadian yang merubah dunia, berkembannya media massa, teknologi komunikasi, serta lahirnya Internet membuat generasi ini tumbuh pada era internet booming. Hal tersebutmembuat generasi millennial berbeda dengan generasi lain, generasi ini cenderung menghabiskan waktunya dalam lingkup digital.

CNN Indonesia Studexxnt menyatakan generasi millennial memiliki beberapa karakteristik, yaitu: 1) Millennial lebih percaya User Generated Content (UGC) daripada informasi searah; 2) Millennial lebih memilih ponsel dibanding TV; 3) Millennial wajib mempunyai media sosial; 4) Millennial kurang suka membaca secara konvensional;5) Millennial lebih tahu teknologi dibanding orang tua; dan 6) Millennial cenderung tidak loyal namun bekerja efektif; dan 7) Millennial mulai banyak melakukan transaksi secara cashless (Alfyonita et al., 2019).

Karakteristik generasi millennial yang sangat bergantung kepada teknologi dan Internet membuat generasi ini seakanakan hidup dalam Internet itu sendiri.

\section{Literasi Digital}

Sebelum memasuki bahasan mengenai literasi digital kita mengakar dahulu dari literasi itu sendiri dalam iringan dominasi media. Konsep literasi bersumber awal dari berkaitan dengan melek huruf, dipahami sebagai kemampuan individu membaca aksara dan medianya. Adiputra (2008) memberikan penjelasan mengenai literasi media:

"Literasi media dapat dibagi dalam tiga kategori, yaitu: the umbrella definition, the process definition, and the purpose definition. Definisi payung menganalogikan literasi media sebagai pelindung individu ketika individu terkena hujan informasi sewaktu berhadapan dengan media. Definisi proses menunjukkan bahwa literasi media adalah sebuah kecakapan yang berfungsi ketika individu mengakses media massa. Sedangkan definisi tujuan menganalogikan literasi media sebagai sebuah hasil akhir dari konstruksi yang dibangun dalam pikiran individu sehingga individu tersebut memiliki kontrol yang lebih besar atas pesan media yang ia terima".

Dalam perkembangannya, konsep mengenai literasi digital muncul seiring dengan dominasi media di tengah kehidupan manusia yang mentransfer data dan informasi. Potter mencatat awalnya media literacy didefiniskan sebagai; The ability to access and process information from any form of transmition. Definisi tersebut kemudian mengarah pada "The ability to access, analyse, evaluate, and create messages across a variety of contexts (Livingstone, 2008). Definisi tersebut lebih dimaknai sebagai pendekatan "Life skills". Pengukuran dengan pendekatan lifeskills

Table 2. Kerangka Kompetensi Individu

Kerangka Kompetensi Individu

Kompetensi Personal Kompetensi Sosial

1. Technical Skills Communication Abilities

2. Critical Understandings

Sumber : Olahan Tim Peneliti (2018) 
sendiri bisa dilihat dari kemampuan seseorang menggunakan dan memanfaatkan media. Literasi media dapat diukur dari Individual Competence Framework, seperti yang digunakan dalam Final Report Study on Assesment Criteria for Media Literacy Levels (2009).

Kerangka Kompetensi Individu menyangkut kemampuan seseorang menggunakan media (personal competence) dan kemampuan seseorang berkomunikasi dan membangun relasi sosial, media, serta mampu memproduksi konten media (social competence): a) Kompetensi Personal terdiri dari: technical skills yang berhubungan dengan kemampuan menggunakan Komputer dan Internet dan menggunakan media secara aktfif; dan Critical Understandings yang berhubungan dengan kemampuan menggunakan konten dan fungsi media, memiliki pengetahuan mengenai media dan regulasinya serta perilaku dalam menggunakan media; b) Kompetensi Sosial terdiri dari Communication skills yang berkaitan dengan kemampuan komunikasi dan membangun relasi sosial melalui media, kemampuan partisipasi dengan masyarakat melalui media, serta kemampuan untuk memproduksi dan mengkreasikan konten media.

Pertumbuhan media dan fenomenanya ternyata tidak cukup pada permasalahan mengenai life skills saja. Pendekatan ini menuntut konsumsi media dalam intensitas tinggi, kemudian Potter mengembangkan literasi media sebagai " a set of perspective that we actively use to expose ourselves to the media and interpret the meaning of the message we encounter. It's multidimensionalandacontinuum"(Potter,2013).

Saat dunia memasuki abad baru, dimana New Media hadir, kontinum yang disebutkan Potter dalam definisi sebelumnya merupakan sebuah era dimana life skills teknikal tidak cukup untuk menghadapi media. New media tidak hanya bicara soal Internet, World Wide Web atau lompatan perkembanagan teknologi komunikasi dan informasi. Memahami New Media berkaitan dengan proses proses sosial dan teknologi yang multi dimensional meliputi tiga aspek. Pertama, digitalisasi dan konvergesi. Kedua, aspek interaktivitas. Terakhir, network dan networking. Artinya literasi media membutuhkan perspektif yang baru. Kemudian muncullah konsep mengenaiLiterasi digital dalam peradadaban baru.

Literasi digital tidak lepas dari kemampuan seseorangdalammenggunakandanmemanfaatkan teknologi dan media digital. Spiers dan Bartlett (2012) dalam (Paul, 2005) membagi berbagai proses intelektual terkait penggunaan teknologi dan media digital menjadi tiga kategori, yaitu menemukan dan mengonsumsi konten digital, membuat atau memproduksi konten digital, dan mengkomunikasikan konten digital. Mencari dan mengonsumsi konten digital adalah keterampilan menemukan, memahami, dan mengonsumsi konten digital di Web. Inti dari menjadi efektif dengan Web adalah menemukan informasi secara strategis dan mengevaluasi akurasi dan relevansinya (Leu etal., 2008) dalam (Paul, 2005).

Perkembangannya, digital literacy atau tepatnya digital literacies didefinisikan sebagai 'practices of communicating, relating, thinking and 'being' associated with digital media' (Jones \& Hafner, 2012). Definisi ini bersumber dari akar konsepsi perkembangan media digital sebagai social phenomenon - fenomena sosial, yang membawa berbagai konsekuensi ekonomi, sosial dan politik. Istilah 'practices' dipilih karena konsep ini mencakup segala cara untuk memanfaatkan literasi secara aktif, termasuk aktivitas pemaknaan yang melandasinya. "Literacy practices are made up of specific activities and at the same time are part of broader social processes... The concept provides the route map for thinking about topics as diverse as the role of agency, and the significance of the body, objects and texts. It clarifies the relations of actions and discourse ... Human life are made up of social practices. That is the reason why we emphasize people's lived experiences and everyday relations to technologies ..." (Barton \& Lee, 2010). "Digital literacies' involve not just being able to 'operate' tools like computers and 
mobile phones, but also the ability to adapt the affordances and constraints of these tools to particular circumstances ... In other words, while we may seem at times to focus quite heavily on the 'digital' part of digital literacies, that is, to dwell on the affordances and constraints of these new technologies, what we are really interested in is not the tools themselves, but the process of mediation, or, as others called it, mediated action (Scollon, 2001; Wertch, 1993), the process through which people appropriate these tools to accomplish particular social practices (Jones \& Hafner, 2012)". "A digitally literate person: (1) Possesses the variety of skills - technical and cognitive - required to find, understand, evaluate, create, and communicate digital infor-mation in a wide variety of formats; (2) Is able to use diverse technologies appropriately and effectively to re-trieve information, interpret results, and judge the quality of that in-formation; (3) Understands the relationship between technology, life-long learning, personal privacy, and stewardship of information; (4) Uses these skills and the appropriate technology to communicate and collaborate with peers, colleagues, family, and on occasion, the general public; and (5) Uses these skills to actively participate in civic society and contribute to a vibrant, informed, and engaged community" (ALA Digital Literacy Taskforce, 2011)

Pemaknaan bahwa literasi digital adalah sebuah konsep yang mengarah pada mediasi antara teknologi dengan khalayak atau user untuk mempraktikkan teknologidigital secara produktif. Hague dan Payton juga mengemukakan bahwa literasi digital merupakan kemampuan untuk membuat dan berbagi dalam mode dan bentuk yang berbeda; untuk membuat, berkolaborasi, dan berkomunikasi lebih efektif, serta untuk memahami bagaimana dan kapan menggunakan teknologi digital yang baik untuk mendukung proses tersebut (Hague \& Payton, 2010). Dengan demikian, dapat disimpulkan bahwa karakteristik literasi digital tidak hanya mengacu pada keterampilan operasi dan menggunakan berbagai perangkat teknologi dan media digital, tetapi juga terkait bagaimana seseorang dapat memanfaatkan teknologi dan media digital untuk memproduksi, berbagi dan mengkonsumsi konten media digital secara selektif dan kritis.

Digital Literacy Across the Curriculum (Hague \& Payton, 2010) dijelaskan ada 8 komponen literasi digital, yaitu: a) Functional Skill and Beyond, merupakan komponen pertama berkaitan dengan operasional teknologi. Berkaitan dengan kemampuan ICT-Skills seseorang dan relasinya dengan konten dari berbagai media. Penggunaan operasional dari teknologi juga berkaitan dengan familiaritas terhadapteknologi,keterjangkauanalatteknologi, penggunaan teknologi dan menghasilkan data, kesadaran mengenai copyright dan mampu menghasilkan produk akhir dari teknologi; b) Creativity, merupakan komponen creativity berkaitan dengan cara berpikir dan membangun serta membagikan pengetahuan dalam berbagai macam ide dengan memanfaatkan teknologi digital. Dalam hal ini creativity disebut mencakup; (1) kreasi produk atau keluaran dalam berbagai format dan model dengan memanfaatkan teknologi digital; (2) kemampuan berpikir kreatif dan imajinatif meliputi perencanaan, merajut konten, mengeksplorasi ide ide dan mengkontrol proses kreatifnya; c) Collaboration, merupakan komponen Collaboration didasarkan pada sifat teknologi digital itu sendiri. Teknologi digital menyediakan peluang peluang untuk bekerjasama dalam tim. Teknologi digital juga membuka proses partisiopasi yang kemudian membuka dukungan untuk kolaborasi. Komponen ini menekankan partisipasi individu dalam proses dialog, diskusi dan membangun gagasan gagagsan lainnya untuk menciptakan pemahaman. Misalnya, kemampuan berpartisipasi dalam ruang digital, mampu menjelaskan dan menegosiasikan gagasan-gagasan dengan orang lain di grup; d) Communication, merupakan seseorang yang terliterasi digital berarti menjadi orang yang mampu berkomunikasi melalui media teknologi digital. Komunikasi yang efektif dan literasi 
digital erat dengan kemampuan membagikan pemikiran, gagasan dan pemahaman. Selain itu memiliki kemampuan memahami dan mengerti audiens (sehingga keika membuat konten mereka memperkirakan kebutuhan audiens dan dampaknya); e) The Ability to find and select Information, merupakan komponen ini menitikberatkan pada kemampuan mencari dan meyeleksi informasi pada digital literacy across the curriculum (2009). Kemampuan ini berkaitan dengan bagaimana berpikir hati-hati mengenai bagaimana proses pencarian informasi dan menggunakan sumber secara selektif; f) Critical

Thinking and Evaluation, merupakan komponen ini menekankan bahwa jangan hanya menerima informasi dan memaknai informasi secara pasif saja tapi sebaiknya juga berkontribusi, menganalisis dan menajamkan berpikir kritis saat berhadapan dengan informasi; e) Cultural and Social Understanding, merupakan praktik literasi digital sebaiknya sejalan dengan konteks pemahaman sosial dan budaya; f) E-Safety, merupakan komponen E-Safety menekankan pada pada pilihan pilihan yang menjamin keamanan saaat pengguna bereksplorasi, berkreasi, berkolaborasi dengan teknologi digital.

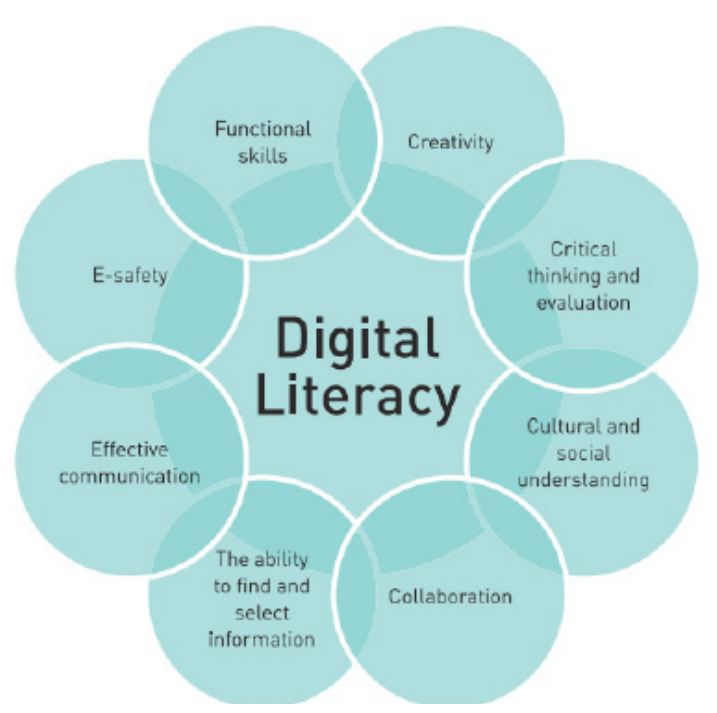

Gambar 1. Komponen Literasi Digital Sumber: Digital Literacy Across the Curriculum (Hague \& Payton, 2010)
Jika melihat pengukuran aspek aspek literasi media di sub bab sebelumnya, literasi digital memiliki komponen penilaian yang tidak berbeda jauh. Meski literasi digital memiliki perspektif yang lebih luas dan multidimensional daripada literasi media. Komponen komponen literasi media yang menggunakan pendekatan lifeskills pun masih ada pada komponen literasi digital.

Penelitian ini bertujuan untuk memetakan tingkat literasi digital generasi milenial di Kabupaten Jawa Barat, sehingga dapat membantu Universitas Telkom, pemerintah daerah dan pemerintah pusat (Kominfo) dalam mengambil keputusan terkait masalah format pendidikan literasi digital yang sesuai dengan kondisi di lapangan. Penelitian ini untuk dapat memetakan kemampuan generasi milenial dalam menggunakan media digital, berelasi di dunia digital dan memproduksi konten positif media digital.

\section{Metode Penelitian}

Penelitian ini menggunakan metode penelitian kuantitatif dengan format penelitian eksplanatif. Sugiyono menyampaikan bahwa metode kuantitatif ini disebut juga sebagai metode positivistik karena berlandaskan pada filsafat positivisme, selain itu juga disebut sebagai metode ilmiah (scientific) karena telah memenuhi kaidah-kaidah ilmiah yaitu konkrit atau empiris, obyektif, terukur, rasional dan sistematis (Sugiyono, 2018). Format penelitian eksplanatif dimaksud untuk menjelaskan suatu generalisasi sampel terhadap populasinya atau menjelaskan 50 hubungan, perbedaan atau pengaruh satu variabel dengan variabel yang lain. Karena itu penelitian eksplanatif menggunakan sampel dan hipotesis (Bungin, 2011). Penelitian ini menggunakan variabel tingkat literasi digital dengan hipotesis tingkat literasi digital di kalangan generasi milenial di Kabupaten Bandung termasuk pada indeks kategori intermediate. Subjek penelitian dalam penelitian 
Tabel 3. Dimensi dan Indikator Penelitian

\begin{tabular}{|c|c|c|}
\hline Dimensi & Indikator & Skala \\
\hline Functional Skill and Beyond & 1. Kemampuan ICT Skills & Ordinal \\
\hline Creativity & $\begin{array}{l}\text { 1. Kreasi produk atau keluaran dalam } \\
\text { berbagai format dan model dengan } \\
\text { memanfaatkan teknologi digital. } \\
\text { 2. Kemampuan berpikir kreatif dan } \\
\text { imajinatif meliputi perencanaan, } \\
\text { merajut konten, mengeksplorasi ide-ide } \\
\text { dan mengontrol proses kreatifitas }\end{array}$ & Ordinal \\
\hline Collaboration & $\begin{array}{l}\text { 1. Kemampuan berpartisipasi dalam } \\
\text { ruang digital } \\
\text { 2. Mampu menjelaskan dan } \\
\text { menegosiasikan gagasan-gagasan } \\
\text { dengan orang lain di grup }\end{array}$ & Ordinal \\
\hline Communication & $\begin{array}{l}\text { 1. Mampu berkomunikasi melalui } \\
\text { media teknologi digital } \\
\text { 2. Kemampuan memahami dan } \\
\text { mengerti audiens (sehingga ketika } \\
\text { membuat konten mereka } \\
\text { memperkirakan kebutuhan audiens dan } \\
\text { dampaknya) }\end{array}$ & Ordinal \\
\hline $\begin{array}{l}\text { The Ability to find and select } \\
\text { Infomation }\end{array}$ & $\begin{array}{l}\text { Kemampuan mencari dan menyeleksi } \\
\text { informasi }\end{array}$ & Ordinal \\
\hline $\begin{array}{l}\text { Critical Thinking and } \\
\text { Evaluation }\end{array}$ & $\begin{array}{l}\text { Mampu berkontribusi, menganalisis dan } \\
\text { menajamkan berpikir kritis saat } \\
\text { berhadapan dengan informasi }\end{array}$ & Ordinal \\
\hline $\begin{array}{l}\text { Cultural and Social } \\
\text { Understanding }\end{array}$ & $\begin{array}{l}\text { Sejalan dengan konteks pemahaman } \\
\text { sosial dan budaya }\end{array}$ & Ordinal \\
\hline E-safety & $\begin{array}{l}\text { Menjamin keamanan saat pengguna } \\
\text { bereksplorasi, berkreasi, berkolaborasi } \\
\text { dengan teknologi digital }\end{array}$ & Ordinal \\
\hline
\end{tabular}

Sumber : Olahan Tim Peneliti (2018)

ini adalah generasi milenial di Kabupaten Bandung, Provinsi Jawa Barat. Objek penelitian dalam penelitian ini adalah indeks literasi digital. Penelitian ini terdiri atas 8 dimensi literasi digital dari (Hague \& Payton, 2010) dengan penjabaran indikator-indikator seperti tabel 3 .

Teknik analisa data dilakukan dengan pengukuran skor level Indeks Literasi Digital dilihat dari penghitungan skala 1-6 mengadaptasi dari pengukuran Chris Wornshop dalam (Juditha, 2013) yang membagi menjadi 6 level skor : Level 1 = dalam kuesioner menjawab , Tidak Tahu, Level 2 = dalam kuesioner menjawab Sangat Tidak Setuju, Level $3=$ dalam kuesioner menjawab Tidak Setuju, Level $4=$ dalam kuesioner menjawab Kurang. Setuju, Level 5 = dalam kuesioner menjawab Setuju; dan Level $6=$ dalam kuesioner menjawab Sangat
Setuju. Kemudian peneliti membagi Indeks Literasi Digital berdasar nilai Mean (skor) dalam bentuk prosentase yang dituangkan ke 3 (tiga) kategori sebagai berikut; Kategori Indeks Literasi Digital BASIC dengan skor mean 17\%-45\%, Kategori Indeks Literasi Digital INTERMEDIATE dengan skor mean 45,1\%-73\%, Kategori Indeks Literasi Digital ADVANCE dengan skor mean 73\% - 100\%.

Untuk tingkat literasi media khusus menganalisa, mengevaluasi, dan mengkomunikasikan karena sifatnya mengukur sikap maka skornya, yaitu: Level $1=$ dalam kuesioner menjawab Tidak Tahu; Level 2 $=$ dalam kuesioner menjawab Sangat Tidak Setuju; Level 3 = dalam kuesioner menjawab Tidak Setuju; Level $4=$ dalam kuesioner menjawab Kurang Setuju; Level $5=$ dalam 
kuesioner menjawab Setuju; Level $6=$ dalam kuesioner menjawab Sangat Setuju.

Pengumpulan data dilakukan dengan cara menyebar kuesioner secara langsung kepada para responden di sekolah. Subjek dalam penelitian ini adalah Remaja di 3 sekolah di Kabupaten Bandung, yaitu SMA Telkom, SMK Telkom dan SMA Negeri Dayeuhkolot dan objek penelitiannya adalah Indeks Literasi Digital. Populasinya yaitu remaja di kabupaten Bandung dengan sampel sebanyak 500 orang di 3 sekolah sesuai dengan standart limit theorm. Teknik penarikan sampel penelitian ini menggunakan multi stage (purposive sampling) danaccidentalsampling. Kriteriadariresponden pada penelitian ini dijelaskan dalam tabel 4 .
Batasan Penelitian sebagai berikut: (1) Populasi dari penelitian ini adalah remaja pelajar SMA di wilayah kabupaten Bandung. Penelitian ini ditujukan pada sampel yakni remaja pelajar SMA/SEDERAJAT baik itu perempuan dan laki laki (2) Lingkup penelitian, kewilayahan penelitian ini dibatasi pada wilayah urban di Kabupaten Bandung mengingat penetrasi internet paling besar di kawasan urban (data APJII 2017) dengan mengambil 3 sekolah (3) Batasan usia responden pada usia 13-18 tahun memgacu pada data APJII 2017 Penetrasi internet mayoritas di usia 13-18 tahun (75\%). (4) Penelitian ini tidak dimaksudkan melakukan generalisasi indeks literasi digital secara keseluruhan, namun merupakan gambaran awal literasi digital di Kabupaten Bandung dimulai dari wilayah urban.

Tabel 4. Kriteria Responden Penelitian

\begin{tabular}{lll}
\hline \multicolumn{1}{c}{ Kriteria Responden } & \multicolumn{1}{c}{ Alasan } \\
\hline Usia $13-18$ tahun & Data APJI 2017 menampilkan bahwa \\
& penetrasi pengguna internet mayoritas \\
& berdasarkan usia 13- 18 tahun $(75,50 \%)$ \\
& usia $19-34(74,23 \%)$. \\
& Batas usia untuk siswa SMA berdasarkan \\
& Permendikbud Nomor 14 Tahun 2018
\end{tabular}

Jenis Kelamin Perempuan atau Laki-laki

SES

Pendidikan SMA/Sederajat
Data APJI hampir berimbang antara lakilaki dan perempuan

\begin{tabular}{|c|c|c|}
\hline & $\begin{array}{l}\text { Kelompok A (Strata Ekonomi Sosial Atas) } \\
\text { - Kelompok B (Strata Ekonomi Sosial } \\
\text { Menengah Atas) }\end{array}$ & $\begin{array}{l}\text { Berdasarkan survey riset APJII } 2017 \\
\text { penetrasi penggunaan internet lebih tinggi } \\
\text { pada kelompok A dan B }(93,10 \% \text { dan } \\
82,35 \%)\end{array}$ \\
\hline & $\begin{array}{l}\text { Kelompok C (Strata Ekonomi Sosial } \\
\text { Menengah Bawah) - D (Strata Ekonomi } \\
\text { Sosial Bawah) }\end{array}$ & $\begin{array}{l}\text { Berdasarkan survey riset APJII } 2017 \\
\text { dimana komposisi pengguna internet } \\
74,62 \% \text { adalah kelompok C dan } 7,39 \% \\
\text { kelompok D }\end{array}$ \\
\hline SES & SMA/Sederajat & $\begin{array}{l}\text { Tahun } 2018 \text { generasi milenial yang terlahir } \\
\text { terakhir berusia } 18 \text { tahun, di masa remaja } \\
\text { mereka di akhir usia sekolah menengah. }\end{array}$ \\
\hline
\end{tabular}

Sumber : Olahan Tim Peneliti (2018) 


\section{Jenis Kelamin}

\section{Laki-laki $\quad$ Perempuan}

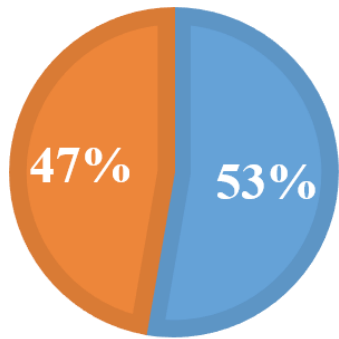

Gambar 2. Data Jenis Kelamin Responden

Sekolah

SMA Telkom Bandung SMK Telkom Bandung - SMA 1 Dayeuhkolot

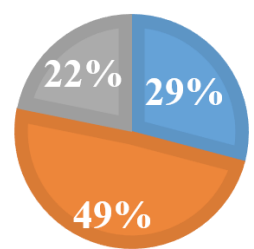

Gambar 3. Data Asal Sekolah Responden

\section{Hasil Penelitian dan Pembahasan}

Data Hasil Riset Indeks Literasi Digital Generasi Milenial Di Kabupaten Bandung

Berdasarkan hasil pengisian kuesioner oleh 500 orang responden dalam penelitian survei ini, didapat data responden berdasar jenis kelamin yakni responden perempuan pada penelitian ini sebesar $47 \%$ dan responden laki-laki sebanyak 53\% (Gambar 2).

Hasil ini menunjukkan karakteristik responden yang cukup berimbang dilihat dari jenis kelaminnya. Dari hasil survei memperlihatkan, responden penelitian berasal dari tiga sekolah di Kabupaten Bandung. Sebanyak 22\% responden dari SMA 1 Dayeuhkolot, 29\% responden dari SMA Telkom Bandung, dan 49\% responden dari SMK Telkom Bandung. Responden dari SMK Telkom Bandung menjadi mayoritas sampel penelitian ini.

Angka Indeks literasi digital pelajar SMA yang didapatkan untuk kabupaten Bandung adalah 62,56. Menurut hasil perhitungan

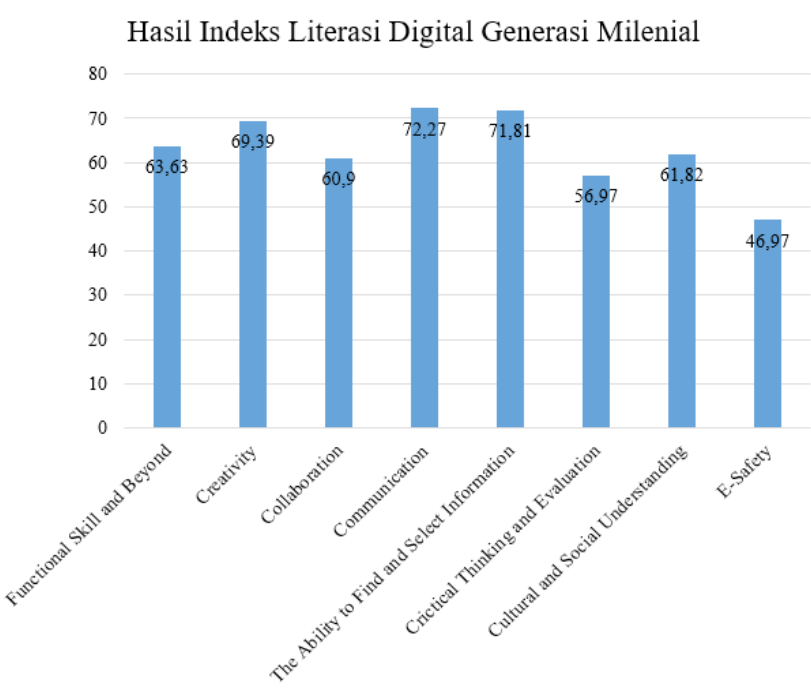

Gambar 4. Hasil Indeks Literasi Digital Per Dimensi

kategori persentase, angka tersebut termasuk ke dalam Level 2 atau intermediate dari 8 dimensi komponen literasi digital. Skor yang tertinggi terdapat pada dimensi The Ability to Find and Select Information dengan skor 71,8. The Ability to Find and Select Information merupakan dimensi yang berkaitan dengan kemampuan seseorang dalam mencari dan menyeleksi informasi. Disini seseorang tersebut dituntut untuk berhati-hati dalam berfikir mencari informasi serta sumber yang selektif. Menjadi seseorang yang terliterasi digital berarti menjadi orang yang mampu berkomunikasi melalui media teknologi digital. Komunikasi yang efektif dan literasi digital erat dengan kemampuan membagikan pemikiran, gagasan dan pemahaman. Kemampuan ini berkaitan dengan aspek Communication. Pada penelitian ini, Skor tertinggi kedua ada pada dimensi Communication senilai 69,09. Kemudian skor paling rendah adalah dimensi E-Safety senilai 46,97. Komponen E-Safety menekankan pada pada pilihan pilihan yang menjamin keamanan saaat pengguna bereksplorasi, berkreasi, berkolaborasi dengan teknologi digital. Secara keseluruhan Indeks Literasi Digital adalah 62,56 adalah berkategori intermediate. 
Tabel 5. Indeks Literasi Digital Remaja Kabupaten Bandung

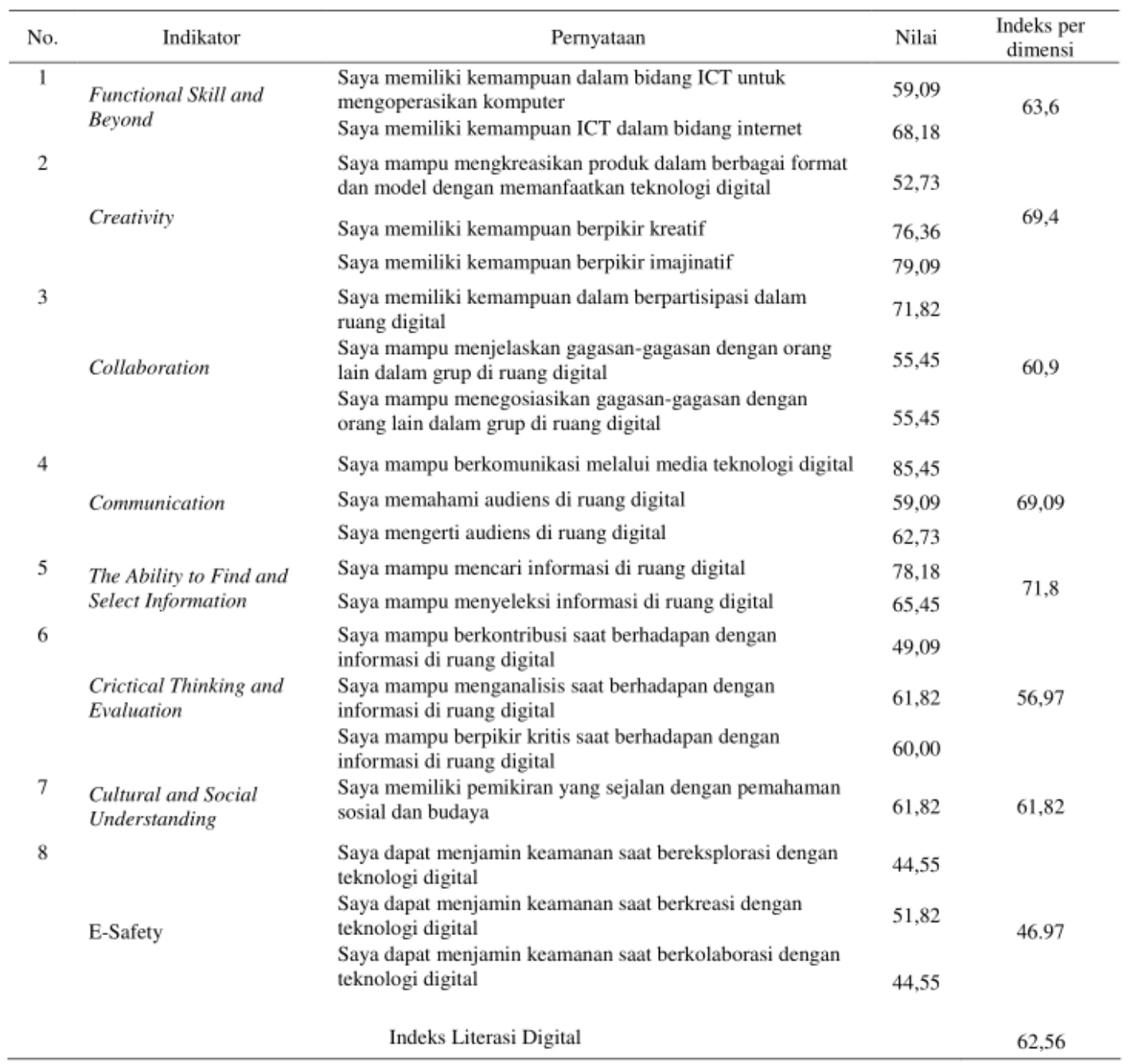

Sumber : Olahan Tim Peneliti (2018)

Secara keseluruhan, Indeks literasi digital pelajar di kabupaten Bandung adalah 62,56. Angka tersebut termasuk ke dalam kategori intermediate dilihat dari delapan komponen Literasi Digital. Komponen Indeks Literasi Digital sendiri terdiri dari dalam digital literacy across the curriculum (Hague \& Payton, 2010) dijelaskan ada 8 komponen literasi digital: (1) Functional Skill and Beyond, (2) Creativity, (3) Collaboration, (4) Communication, (5) The Ability to find and select Information, (6) Critical Thinking and Evaluation, (7) Cultural and Social Understanding, dan (8) E-Safety.
Dari 8 komponen indeks literasi digital tersebut The Ability to Find and Select Information dengan skor 71,8. Komponen ini menitikberatkan pada kemampuan mencari dan meyeleksi informasi. Kemampuan ini berkaitan dengan bagaimana berpikir hati-hati mengenai bagaimana proses pencarian informasi dan menggunakan sumber secara selektif. Generasi milenial dilahirkan dan dibesarkan seiring dengan berbagai kejadian yang merubah dunia, berkembannya media massa, teknologi komunikasi, serta lahirnya Internet membuat generasi ini tumbuh pada era internet booming. Hal tersebut membuat generasi millennial 
berbeda dengan generasi lain, generasi ini cenderung menghabiskan waktunya dalam lingkup digital. Mereka punya kecenderungan lebih percaya User Generated Content (UGC) daripada informasi searah sehingga generasi milenial cukup detil dalam seleksi informasi.

\section{Komponen Communication menjadi} komponen tertinggi kedua dari hasil penelitian ini. Menjadi seseorang yang terliterasi digital berarti menjadi orang yang mampu berkomunikasi melalui media teknologi digital. Komunikasi yang efektif dan literasi digital erat dengan kemampuan membagikan pemikiran, gagasan dan pemahaman. Selain itu memiliki kemampuan memahami dan mengerti audiens (sehingga ketika membuat konten mereka memperkirakan kebutuhan audiens dan dampaknya). Dalam riset ini generasi milenial di kabupaten Bandung pada dasarnya akrab dengan teknologi sehingga mereka mampu memprediksi kebutuhan user lain yang juga generasai milenial seperti mereka. Secara teknis mereka menguasai teknologi digital sekaligus fleksibel ketika membangun relasi komunikasi dalam ruang virtual.

Terdapat bentuk peringatan akibat intensitas mereka mengakses teknologi digital, yaitu berkaitan dengan E-Safety. Komponen ini yang memiliki skor terendah. E-Safety sendiri merupakan komponen yang menekankan pada pada pilihan-pilihan yang menjamin keamanan saaat pengguna bereksplorasi, berkreasi, berkolaborasi dengan teknologi digital. Hal ini perlu menjadi pertimbangan edukasi mengenai cyber-security dalam meningkatkan kewaspadaan pada generasi milenial. Urgensi mengenai literasi digital juga sejalan dengan concern negara (pemerintah) dalam membekali masyarakat dengan edukasi yang cukup sehingga dapat menggunakan teknologi dan media digital secara optimal dan aman.
Sebagaimana disampaikan Setiawan pada Seminar Pendidikan Nasional pada 2017, era digital saat ini harus disikapi dengan serius, dengan menguasai dan mengendalikan peran teknologi dan media digital dengan baik agar era digital membawa manfaat bagi kehidupan (Setiawan, 2017). Dunia pendidikan harus menjadi media utama untuk memahami, mengusai, dan memperlakukan teknologi dengan baik dan benar. Remaja harus diberikan pengertian dengan era digital ini baik manfaat positif maupun ekses negatifnya. Selain itu, literasi digital untuk remaja menjadi hal yang penting dilakukan karena usia muda adalah kalangan yang paling rentan dalam mengkonsumsi media digital (Silvana \& Darmawan, 2018).

\section{Simpulan}

Pemaknaan bahwa literasi digital adalah sebuah konsep yang mengarah pada mediasi antara teknologi dengan khalayak atau user untuk mempraktikkan teknologi digital secara produktif. Hasil Akhir menunjukkan nilai indeks literasi digital di angka 62,56 atau pada indeks kategori intermediate pada generasi milenial Kabupaten Bandung Jawa Barat. Komponen tertinggi ada pada dimensi The Ability to Find and Select Information dengan skor 71,8. Skor tertinggi kedua ada pada dimensi Communication senilai 69,09. Kemudian skor paling rendah adalah dimensi E-Safety senilai 46,97. Ini memberikan gambaran bahwa generasi milenial di SMA atau SMK di kabupaten Bandung perlu meningkatkan Literasi Digital pada aspek E-Safety. Hasil penelitian ini dapat menjadi pemetaan awal atas tingkat literasi digital remaja di Kabupaten Bandung yang dapat menjadi dasar dalam pengambilan kebijakan terkait literasi digital remaja. Dengan demikian, pemerintah dapat mengmbil kebijakan yang tepat dalam pembekalan edukasi kepada para siswa tentang pemanfaatan teknologi digital secara optimal dan aman. 
Daftar Pustaka

A'yuni, Q. Q. (2015). Literasi Digital Remaja Di Kota Surabaya. Jurnal Fakultas Ilmu Sosial Dan Ilmu Politik Universitas Airlangga Surabaya, 4(2), 1-15. Diakses dari http://journal.unair.ac.id/ literasi-digital-remaja-di-kota-surabayaarticle-9195-media-136-category-8.html Alfyonita, D., Nasionalita, K., Sos, S., Prodi, S., Komunikasi, I., Komunikasi, F., \& Telkom, U. (2019). Konstruksi Identitas Generasi Millennial Di Kota Bandung Dalam Media Sosial Instagram Identity Construction Of Millennial Generation In Bandung On Instagram. In Openlibrary Telkom University (Issue Communication Science). https://openlibrary.telkomuniversity.ac.id/ pustaka/147559/konstruksi-identitasgenerasi-millennial-di-kota-bandungdalam-media-sosial-instagram.html

Barton, D., \& Lee, C. (2010). Literacy studies. In The SAGE Handbook of Sociolinguistics. https://doi.org/10.4135/9781446200957.n39

Bawden, D. (2017). Information and digital literacies: a review of concepts. August. https://doi. org/10.1108/EUM0000000007083 Bungin, B. (2011). Penelitian Kualitatif: Komunikasi, Ekonomi, Kebijakan Publik, Dan Ilmu Sosial Lainnya. In Kencana. https://doi.org/10.1002/jcc.21776 Hague, C., \& Payton, S. (2010). Digital literacy across the curriculum Key to themes: A Futurelab handbook. www.futurelab.org.uk Home, N., \& Strauss, W. (2018). Millenials Rising: The Next Generation. Small Business and the City. https://doi. org/10.3138/9781442696501-014 Jones, R. H., \& Hafner, C. A. (2012). Understanding digital literacies: A practical introduction. In Understanding Digital Literacies: A Practical Introduction. https://doi.org/10.4324/9780203095317
Juditha, C. (2013). Literasi Media pada Anak di Daerah Perbatasan Indonesia dan Timor Leste. JURNAL IPTEKKOM: Jurnal Ilmu Pengetahuan \& Teknologi Informasi. https://doi. org/10.33164/iptekkom.15.1.2013.47-62

Lancaster, L. C., \& Stillman, D. (2011). The "M Factor - How the Millennial Generation is Rocking the Workpkace." NHRD Network Journal. https://doi. org/10.1177/0974173920110428

Lankshear, C., \& Knobel, M. (2006). Digital literacy and digital literacies. Nordic Journal of Digital Literacy, 1(April 2016), 12-24. https://doi.org/10.1108/EL-05-2015-0076

Livingstone, S. (2008). Taking risky opportunities in youthful content creation: Teenagers' use of social networking sites for intimacy, privacy and self-expression. New Media and Society. https://doi.org/10.1177/1461444808089415

Lyons, S. (2004). An exploration of generational values in life and at work. In ProQuest Dissertations and Theses. Martin, C. A., \& Tulgan, B. (2012). Managing the Generation $\mathrm{Mix}^{\mathrm{TM}}$ - From Collision to Collaboration. Proceedings of the Water Environment Federation. https:// doi.org/10.2175/193864703784755210

Novianti, Fatonah, Siti, D. (2016). Model Literasi Media di Lingkungan Ibu-Ibu Rumah Tangga di Yogyakarta (Studi Pada Kec. Gondomanan Yogyakarta dan Kec. Banguntapan Bantul Di Yogyakarta). Jurnal Ilmu Komunikasi, 14(2), 101-113. Diakses dari http://jurnal.upnyk.ac.id/ index.php/komunikasi/article/view/2124

Paul, C. M. (2005). Encyclopedia of information science and technology. Choice Reviews Online, 43(01), 43-0002-43-0002. https://doi.org/10.5860/choice.43-0002 Potter, W. J. (2013). Review of literature on media literacy. Sociology Compass. https://doi.org/10.1111/soc4.12041 Purbo, O. W. (2018). 5. Narrowing the digital divide. In Digital Indonesia. https:// doi.org/10.1355/9789814786003-011 
Rogers, E. M. (2001). The digital Divide. Convergence. https://doi. org/10.1177/135485650100700406

Setiawan, W. (2017). Era Digital dan Tantangannya. In Seminar Pendidikan Nasional 2017 (pp. 1-9). Universitas Pendidikan Indonesia.

Silvana, H., \& Darmawan, C. (2018). Pendidikan Literasi Digital Di Kalangan Usia Muda
Di Kota Bandung. Pedagogia, 16(2), 146. https://doi.org/10.17509/pdgia.v16i2.11327 Sugiyono. (2018). Metode Penelitian Kuantitatif,Kualitatif dan R\&D. In $\mathrm{Ke}-26$. Adiputra, W. M. (2008). Literasi Media dan Interpretasi atas Bencana. Jurnal Ilmu Sosial Dan Ilmu Politik, 11(3), 357378. https://doi.org/10.22146/jsp.10992 Yanuar Surya Putra. (2016). Theoritical Review: Teori Perbedaan Generasi. Among Makarti. 